\title{
敗血症治療に黄耆建中湯が有効であった一例
}

\author{
南澤 潔 古田 一史 $^{\mathrm{b}}$ 三潴 忠道 ${ }^{\mathrm{b}}$ \\ 寺澤 捷年 ${ }^{\mathrm{a}}$
}

a 富山医科薬科大学医学部和漢診療学講座, 富山, $\overline{0} 930-0194$ 富山市杉谷2630

b 麻生(侏飯塚病院漢方診療科, 福岡, $\overline{7} 820-8505$ 飯塚市芳雄町 3-83

\section{A Case of Septic Patient Treated with Ogi-kenchu-to}

\author{
Kiyoshi MINAMIZAWA $^{\mathrm{a}}$ Kazufumi KOUTA $^{\mathrm{b}}$ Tadamichi MITSUMA $^{\mathrm{b}}$ \\ Katsutoshi TERASAWA ${ }^{\mathrm{a}}$
}

a Department of Japanese Oriental (Kampo) Medicine, Toyama Medical and Pharmaceutical University, 2630 Sugitani, Toyama 930-0194, Japan

b Department of Japanese Oriental Medicine, lizuka Hospital, 3-83 Yoshio-cho, Iizuka-shi, Fukuoka, 820-8505 Japan

\begin{abstract}
We report a case of an 84-year-old septic patient who was treated with Ogi-kenchu-to (Huang-qj-jian-zhong -tang). The patient had remained positive for Klebsiella pneumoniae. The focus of infection had not been detected, but bacterial translocation from the digestive tract was suspected from the clinical course. After two weeks of antibiotic therapy, he still had a high fever and positive blood culture. In addition, multiple cultures showed the destruction of normal flora and an increase of antibiotics-resistant bacteria.

Antibiotics were then suspended, and he was treated with Ogi-kenchu-to alone. His fever and inflammatory signs gradually disappeared, and his blood cultures became negative without restarting antibiotic treatment. He recovered completely. Ogi-kenchu-to is indicated for treating "generally weakened" patients or patients with intestinal problems. However, we could not find any reports of its application to septic patients. Although we still need to determine the mechanism for its efficacy, we consider that this case adds further evidence that Ogi -kenchu-to may be helpful for those suffering from severe infection, especially in elder patients and immunosuppressed patients.
\end{abstract}

Key words : Ogi-kenchu-to, sepsis, Klebsiella pneumoniae

\section{要旨}

抗生物質治療に抵抗性であった84歳男性の敗血症患者に対して，黄耆建中湯が奏功した症例を経験した。患者の 血液培養からは継続してクレブシエラが検出され，明らかで無しながら感染源として腸管からの bacterial translocation が疑われた。2 週間の抗生物質治療にも関わらず弛張熱と血液培養陽性が持続し，菌交代現象が示唆された。 このため抗生物質を中止の後，黄耆建中湯単独にて加療したところ徐々に発熱，炎症反応の低下が見られ，抗生物 質を再開することなく血液培養も陰性化し，患者は完全に回復した。黄㔫建中湯は「虚労を治す」とされているが， 敗血症治療に奏功したとの報告は見られない。機序は明らかでないが，黄耆建中湯が特に高齢者や免疫機能低下状 態の重篤な感染症の治療に有用である可能性が示唆された。

キーワード : 黄耆建中湯，敗血症，クレブシエラ

\section{緒言}

抗生物質の開発以来, 人類は感染症に対して優勢 を得るようになったが, HIV (Human Immunodeficiency Virus）に代表される新種の病原体の出現や, 近年とみに問題化している耐性菌の増加など, 最近 ではその圧倒的優位が崩れつつあるといえよう。毎 年のように新種の抗菌薬の開発とそれに対する耐性 菌の出現が繰り返されている現状は，「病源を外部
から破壊，除去することで治癒を目指す」，という ストラテジーの限界を示唆するとも考えられる。

今回我々は抗生物質治療に不応であった敗血症に 対して，黄者建中湯が奏功したと思われる症例を経 験した。今後ますます問題化するであろう超高齢者 の感染症対策として, 様々な示唆に富むと考えられ るので若干の考察を加え報告する。 


\section{症例}

症 例: 84歳 男性

家族歴：特記すべきことなし

既往歴：1993年：肺結核 1999年：肺炎，膿胸， 肺梗塞

現病歴：1992年より多発性脳梗塞による痴呆症の ため老人ホームに入所中であった。1993年に肺結核 を発症したが, 抗菌薬療法にて速やかに治癒し以後 経過良好であった。1999年に誤䤓性肺炎に対する長 期抗生物質投与の末 MRSA（Methicillin-resistant Staphylococcus aureus）による膿胸を併発。 8 力月 間にわたる長期入院を余儀なくされ下肢拘縮を起こ し, 以後床上生活となった。この際，嚥下障害に対 して胃瘦を造設されている。1999年に退院後, 全身 状態は良好であった。

2000年 5 月, 胃瘦のダンパーが落ち込んで十二指 腸球部に嵌頓。同部に圧迫による潰瘍を形成して出 血を起こし，麻生飯塚病院内科に緊急入院した。

ダンパー除去による圧迫の解除とプロトンポンプ 阻害剂（オメプラゾール20mg）投与で潰瘍は順調 に改善したが, 以前からの前立腺肥大による排尿障 害がこれを契機に悪化し，尿閉から急性腎後性腎不 全を発症した。導尿により腎機能は回復したが，そ の回復期に一日 4 リットルに及ぶ多尿から電解質バ ランスの失調を併発。更に気管支炎, 嘔吐, 吐血,

下痢, 再度の尿閉に続いて $80 / 40 \mathrm{mmHg}$ 程度への血 圧低下が現れた。血圧低下は補液による中心静脈圧 の維持のみでは改善せず, DOA（dopamine）療法 から離脱できなくなるなど, 徐々に全身状態が悪化。 和漢薬治療併用目的にて漢方診療科転科となった。

身体所見：身長 $155 \mathrm{~cm}$ 体重 $53 \mathrm{Kg}$ 血圧 $110 / 62$ 脈拍 $86 /$ 分 体温 $38.2^{\circ} \mathrm{C}$

両側下肢は高度，両側上肢は軽度の拘縮を認める。 意識は嗜眠でJapan Coma Scale I-20相当。全身の 皮膚は浮腫を呈する。胸部聴打診では明らかな異常 は認めない。腹部は平坦で圧痛は明らかでなく, 背 部にも叨打痛を認めない。

和漢診療学的所見：皮膚は浮腫状でぶよぶよして いるが，表面は枯燥気味で自汗が著明。顔面は蒼白。 脈候はやや沈, やや小, やや虚。舌は正常紅だが乾 燥した黒褐色苔を被る。腹力は中等度で両側の腹直 笳は全長にわたって緊張しており，右に軽度の胸脇 苦満を認める。
臨床検査成績：主要な検査成績を衰 1 に示した。 左方偏位を伴う白血球の増加と貧血, 低蛋白血症と 炎症反応の増加, 呼吸性アルカローシス等の異常所 見を認める。

経過：漢方診療科転科後, 諸所見から直ちに黄者 建中湯加当帰の投与を開始した。転科直前とその後 数日間の経過を國 1 に示す。転科数日前より $38^{\circ} \mathrm{C}$ 台 の熱発が見られていたが，転科直後には最高 $40^{\circ} \mathrm{Cに}$ 及ぶ弛張熱を呈し, 白血球数は $60,180 / \mu 1$ にまて著 増した。各種培養検査を施行後, 中心静脈ラインの 入れ替え, 初期治療として広域抗生物質（メロペナ ム・MEPM）1 g/日による化学療法を開始した。

転科前日および当日に施行した血液培養からは後 日，共に Klebsiella pneumoniae が検出されたため， 抗生剂をセフォチアム（CTM） 2 g/日へ変更した。

和漢薬はその後, 脈証から通脈四逆湯を併用し, また当帰を除いて黄者建中湯へ変方した。その結 果，—には意識状態の改善が得られた。

抗生物質投与開始後, 一旦は速やかに解熱がみら

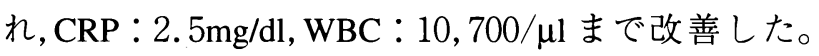
しかしより特に誘因無く再び発熱し, 炎症 反応も増覀した。混合感染を考慮して, いよ り再び抗生剤を broad spectrum の MEPM $1 \mathrm{~g} /$ 日に変 更したが，依然 $39^{\circ} \mathrm{C}$ 台の弛張熱が続き，また

には陰性化していた血液培養であったが,

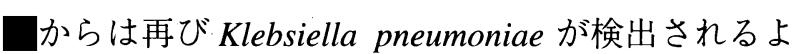
うになった。感染源検索のため, 胸腹部 CT, 腹部 および心エコー検査, 全身 $\mathrm{Ga}$ シンチグラム, 全身 骨シンチグラムなどを施行したものの明らかな感染 源は同定されなかった。なお，便培養では血液培養 と同様に Klebsiella pneumoniae が陽性であったが, 喀痰培養, 尿培養からは常在菌のみしか検出されな かった。

結局，抗生物質による化学療法を 2 週間継続後も なお血液培養は陽性，炎症反応強陽性であり，弛張 熱も遷延した状態であった。また患者は元々MRSA および多剂耐性 Pseudomonas aeruginosa の保菌者で あり，功便培養, 喀痰培養でそれぞれ MRSA および Pseudomonas aeruginosa が検出され始 め, 菌交代現象が懸念された。そこで体内細菌叢の 回復と感染状態の再評価を目的に，【で一旦 抗生物質を全て休薬する事とし, 再度各種培養検査, 画像診断を施行し，感染源の同定に努めた。 
表 1 転科時検査成績

\begin{tabular}{lllrlll}
\hline RBC & $289 \times 10^{4} / \mu \mathrm{l}$ & TP & 5.4 & $\mathrm{~g} / \mathrm{dl}$ & CRP & $12.6 \quad \mathrm{mg} / \mathrm{dl}$ \\
$\mathrm{Hb}$ & $8.9 \mathrm{~g} / \mathrm{dl}$ & $\mathrm{Alb}$ & 2.5 & $\mathrm{~g} / \mathrm{dl}$ & & \\
$\mathrm{Hct}$ & $27.6 \%$ & BUN & 8 & $\mathrm{mg} / \mathrm{dl}$ & $\mathrm{PT}$ & $81.7 \%$ \\
$\mathrm{MCV}$ & $95.8 \mathrm{fl}$ & $\mathrm{Cr}$. & 0.5 & $\mathrm{mg} / \mathrm{dl}$ & FDP & $10 \sim 20 \mu \mathrm{g} / \mathrm{ml}$ \\
& & T.Bil & 0.5 & $\mathrm{mg} / \mathrm{dl}$ & & \\
WBC & $12,500 / \mu \mathrm{l}$ & $\mathrm{GOT}$ & 34 & $\mathrm{IU} / \mathrm{L}$ & & \\
Neut & $81.7 \%$ & $\mathrm{GPT}$ & 18 & $\mathrm{IU} / \mathrm{L}$ & & \\
Lymph & $11.9 \%$ & $\mathrm{LDH}$ & 205 & $\mathrm{IU} / \mathrm{dl}$ & $\mathrm{ABG}:$ & \\
Mono & $5.4 \%$ & $\mathrm{CPK}$ & 530 & $\mathrm{IU} / \mathrm{dl}$ & $\mathrm{PH}$ & 7.529 \\
Eos & $0.0 \%$ & $\mathrm{Na}$ & 137 & $\mathrm{mEq} / \mathrm{l}$ & $\mathrm{PaCO}_{2}$ & $21.3 \mathrm{mmHg}$ \\
Baso & $0.2 \%$ & $\mathrm{~K}$ & 3.4 & $\mathrm{mEq} / \mathrm{l}$ & $\mathrm{PaO}_{2}$ & $79.3 \mathrm{mmHg}$ \\
Plt. & $21.7 \times 10^{4} / \mu \mathrm{l}$ & $\mathrm{Cl}$ & 105 & $\mathrm{mEq} / 1$ & $\mathrm{HCO}_{3}$ & $17.7 \mathrm{mmol} / \mathrm{L}$ \\
\hline
\end{tabular}

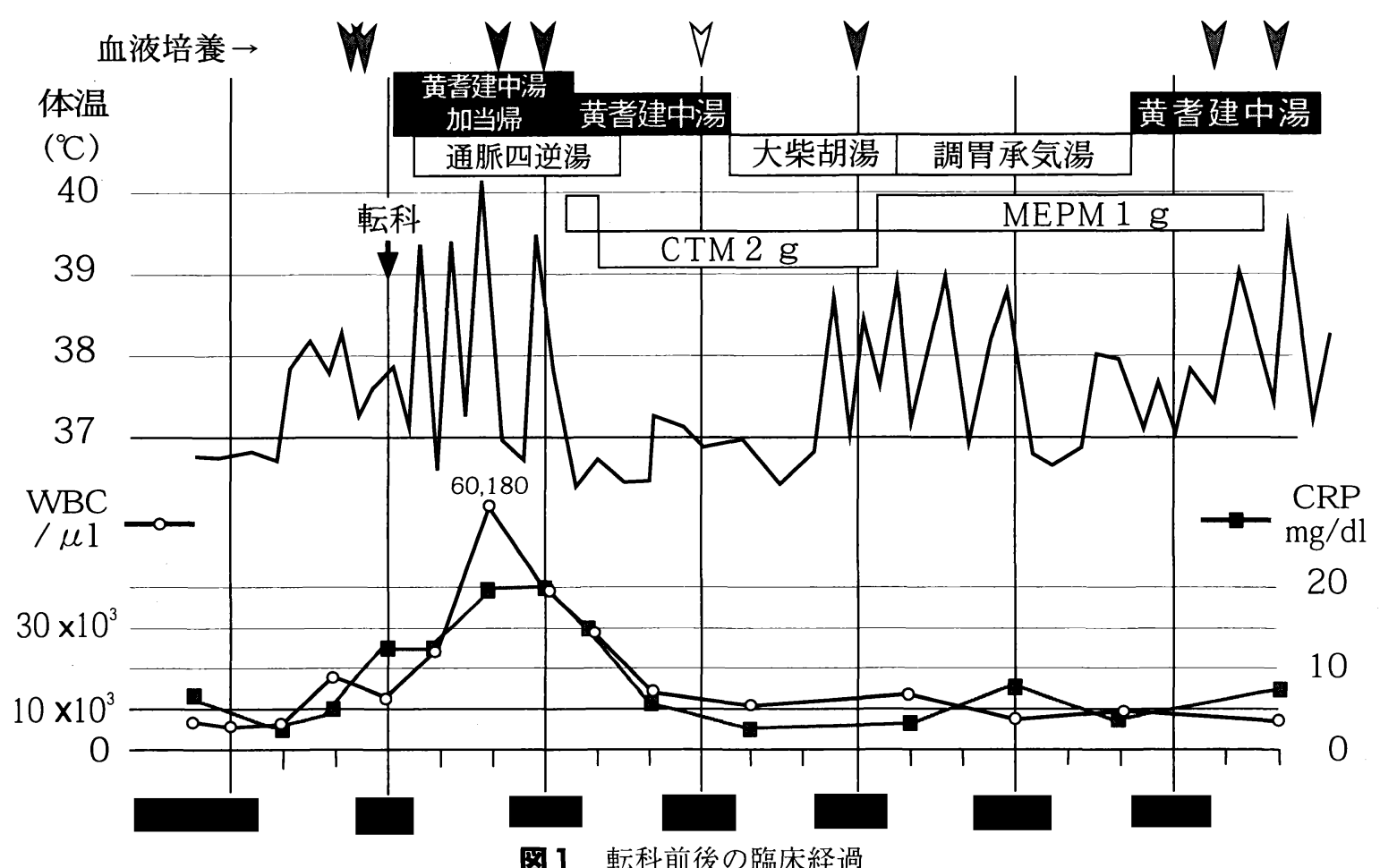

図の最上部の逆三角は，灰色が血液培養陽性，白抜きが培養除性を意味する。

和漢薬は胸脇苦満の増強と便秘から大柴胡湯, つ いで調胃承気湯へと転方していたが原疾患に対して は有効とは言えなかった。そこで全身の虚状を重視 してより再び黄老建中湯へと転方した。こ の前後の臨床経過を图 2 に示した。

抗生物質を中止し，黄者建中湯のみとしたところ， 血圧を始めとした全身状態はむしろ改善傾向となり， ドパミン療法もで中止できた。抗生物質中 止後数日間は発熱, 炎症反応とも悪化したものの,

【より解熱傾向となり，7月に入ると発熱は
消失した。炎症反応も徐々に改善し，抗生物質投与 中も継続して陽性であった血液培養も，

最後に陰性化した。その後は途中で下気道感染を発 症したものの，短期間のアンピシリン/スルバク夕 么 $(\mathrm{ABPC} / \mathrm{SBT}) 3 \mathrm{~g} /$ 日の投与で速やかに改善。以 後は順調に回復し，退院の運びとなった。

\section{考察}

本症例は, 血液培養持続陽性の感染と SIRS（Systemic Inflammatory Response Syndrome) 診断基準 4 項目を全て満たすことから，古典的「敗血症」の状 


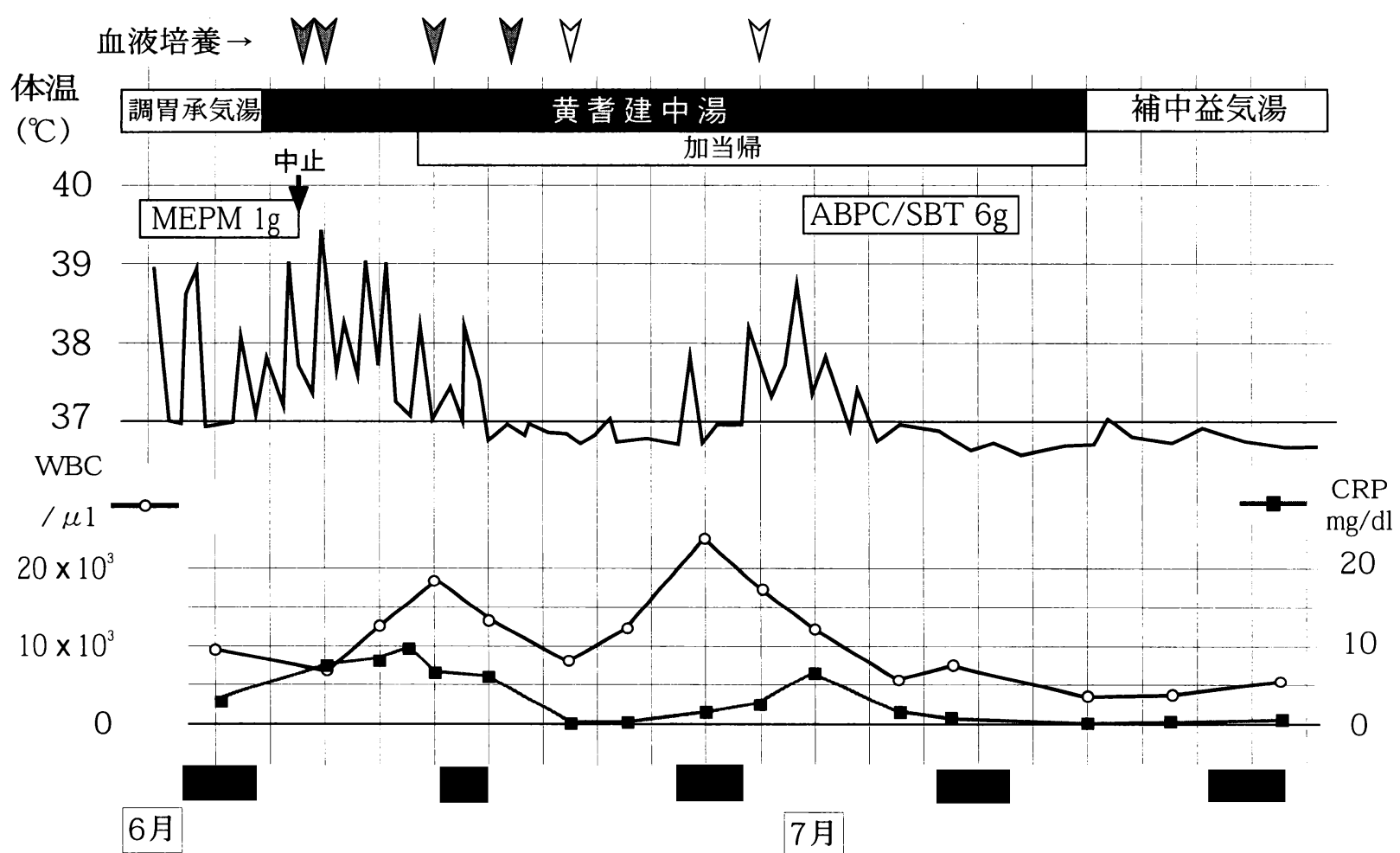

图 2 抗生物質中止前後の臨床経過

図の最上部の逆三角は，図 1 と同様に灰色が血液培養陽性，白抜きが培養陰性を意味する。

検出菌は一貫して Klebsiella pneumoniae であった。

態であったと診断した。敗血症は全身管理の技術が 進歩した現在においても致死率 $16 \%$ ，本症例のよう にSIRS 4 項目を満たす患者では約 $60 \%$ に及ぶ1とさ れる重篤な病態である。さらにグラム陰性桿菌の敗 血症は，エンドトキシンショックから早期の死亡に 至る率が高いとされている ${ }^{21}$ 。治療手段として，エ ンドトキシン吸着療法が循環動態の安定に一定の成 果を上げ，近年は抗サイトカイン療法も注目を浴び ている ${ }^{4)}$ もの, その死亡率はこの数十年殆ど変化 がないる。

そこで近年この病態の見直しが行われており，体 内の反応として炎症が優位の SIRS に対し，炎症抑 制反応が優位の CARS (Compensatory Anti-Inflammatory Response Syndrome) という病態が提唱され ${ }^{5}$, この病態の治療として免疫賦活が注目されている ${ }^{6)}$ 。 病原を攻撃するのみでなく「生体側の防御力を高め る」という新しい治療ストラテジーであるが，IFN $\gamma$

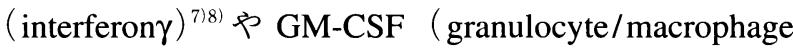
colony-stimulating factor) ${ }^{7}$, G-CSF (granulocyte colony -stimulating factor) ${ }^{9}$ 投 与 や LAK (Lymphokine-activated killer cell）療法 ${ }^{10)}$ 等が試験的に用いられている ものの，まだ確立された免疫賦活法はないのが現状
である。

一方，和漢診療学の世界では補中益気湯を始めと した和漢薬に免疫機能の改善作用があるとの報告が 池田ら ${ }^{11}$ 他, 多数見られる。本症例でも, 転科直後 の黄者建中湯投与後，それまで 1 万台で経過してい た白血球数が, 突然 6 万/ $\mu \mathrm{l}$ 以上にも及ぶ著しい増 加を来しており, 黄者建中湯の投与が患者の免疫機 能を刺激した可能性が考えられる。

黄者建中湯は, 『金實要略 血痺虚労編』に収載 された処方で,「虚労裏急諸不足, 之を主る」と記 述されており，小建中湯と同様に虚弱の改善や慢性 に経過する消耗性疾患に対して広く応用され ${ }^{1213}$ 高 齢者の ADL 改善に有用であるとも報告されてい る ${ }^{14)}$ 。

他方，黄者建中湯は小児アレルギー治療の頻用処

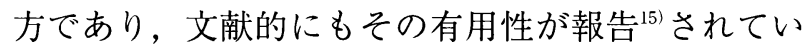
る。近年増加の一途である小児アレルギーの原因と して, 腸管粘膜免疫機構の破綻や未熟性が指摘され ている ${ }^{16)}$ 点を鑑みると, 黄耆建中湯には腸管粘膜機 能改善作用があることも考えられる。本症例におけ る持続する bacteremia の感染源は特定できなかった が, 経過より腸管からの bacteria translocationの存 
在が疑われていた事から，本例の奏功機転の一つと

して腸管粘膜機能改善作用も考えられる。

和漢薬の敗血症への応用例は水島 ${ }^{17} ら$ 他, 数例の 報告 ${ }^{191201}$ があるにすぎないが，実験的には例えば小 柴胡湯にサイトカインやフリーラジカルを制御する ことで，エンドトキシンショックを改善するとの報 告もなされている ${ }^{18)}$ 。

その作用機序については今後の研究課題であるが, 本症例は依然難治である敗血症の治療に際し，和漢 薬治療を積極的に用いることの有用性を示唆すると 思われる。

その際，本症例では経過の遷延から抗生物質を中 止せざるを得なかったが，本来はもっと早期に的確 に証を診断し, 抗生物質療法と並行して用いるべき であろう。

注記：本報告で使用した黄者建中湯の組成, 集散地 は以下の通りである。

黄者 $4.0 \mathrm{~g}$ （中国陝西省）桂枝 $4.5 \mathrm{~g}$ (ベトナム） 药 薬9. $0 \mathrm{~g}$ （奈良県）大呆 $4.5 \mathrm{~g}$ （中国河南省）生姜 $1.0 \mathrm{~g}$ （中国雲南省）采甘草3. $0 \mathrm{~g}$ （内蒙古）膠飴 $20 \mathrm{~g}$ （国 内製)

附記：本論文の要旨は第51回日本東洋医学会総会 （札幌・2001年）にて報告した。

\section{女苚}

1 ) Asayama $\mathrm{K}$ et al. : Evaluation of systemic inflammatory response syndrome criteria as a predictor of mortality in emergency patients transported by ambulance.

Keio. J. Med., 47， 19-27 (1998)

2 ）菅野治重：敗血症血液培養における培地の問題点. 臨床検査, 38, 1386-1392（1994）

3 ）舟田久:【感染症’98】治療の進歩 重篤難治感 染症の治療と進歩 敗血症. 日本内科学会雑誌, 87, 2250-2256 (1998)

4 ) Gullo A: Sepsis and organ dysfunction/failure. An overview. Minerva. Anestesiol., 65, 529-540(1999)

5 ) Bone RC : Sir Isaac Newton, sepsis, SIRS, and CARS. Crit. Care Med., 24, 1125-1128 (1996)

6 ) 古畑智久, 他 : ISIRS と CARS 臓器不全予防のた めの新しい視点】SIRS, CARS の制御に関する一 般知識. 医学のあゆみ，196，67-71（2001）

7 ) Volk HD et al. : Monocyte deactivation-rationale for a new therapeutic strategy in sepss. Intensive. Care Med.,
22 Suppl 4 , S474-481 (1996)

8 ) Kox WJ et al. : Interferon gamma-1 b in the treatment of compensatory anti-inflammatory response syndrome. A new approach : proof of principle. Arch. Intern. Med., 157, 389-393 (1997)

9 ) Gross-Weege W Weiss MSchneider M Wenning M Harms B Dumon K Ohmann C Roher HD : Safety of a low-dosage Filgrastim (rhG-CSF) treatment in nonneutropenic surgical intensive care patients with an inflammatory process. Intensive. Care Medici ne., 23, 16 (1997)

10）峠哲哉, 他：癌のリンパ球移入療法 最近の進歩 癌治療に打けるLAK療法意義. Human. Cell, 5, 218-225 (1992)

11）池田善明, 他：白血球減少症マウスでの補中益気 湯の感染防御効果. 和漢医薬学会誌，3，372-373 (1986)

12）土佐寛順：虚弱老人と漢方. MEDICO， 28，1-3 (1997)

13）松崎茂，他：漢方薬黄者建中湯エキス投与が有効 であった難治性膿胸・腸腰筋膿瘍の 1 例. カレン トテラピー，12，1412-1415（1994）

14）川俣博嗣, 他：漢方の治療 㾛たきり老人の ADL 改善に黄者建中湯が奏効した症例. カレントテラ ピー，14，1307-1309（1996）

15）松浦達雄：乳児のアトピー様皮膚炎に黄者建中湯. 福岡医師漢方研究会会報，11，24-25（1990）

16）名倉宏：【食物アレルギーの最前線】 粘膜免疫機 構と腸内抗原 粘膜免疫と粘膜バリア。医学のあ ゆみ，183，768-772（1997）

17）水島宣昭：プライマリ・ケアにおける漢方エキス 剂の応用（第 4 報）敗血症ないし菌血症における 滋陰降火湯の効能と免疫能. 和漢医薬学会誌,

2, 140-141 (1985)

18）坂口修平：敗血症性ショックモデルとしてのエン ドトキシンと漢方方剤小柴胡湯。東北薬科大学研 究年報，(45)，19-37（1998）

19）川崎君王，他：葛根湯の投与が敗血症の支持両方 として有益と思われた肝細胞癌の 1 例. 漢方診療, 14, 22-24 (1995)

20）岩崎勲：急性感染症に対する小柴胡去半夏加瓜呂 根湯の使用経験. 日本東洋医薬学会誌，44，541546 (1994) 